\title{
Plants Used in Antivenom Therapy in Rural Kenya: Ethnobotany and Future Perspectives
}

\author{
Timothy Omara $\mathbb{1 D}^{1,2,3}$ \\ ${ }^{1}$ Department of Chemistry and Biochemistry, School of Sciences and Aerospace Studies, Moi University, Eldoret, Kenya \\ ${ }^{2}$ Africa Centre of Excellence II in Phytochemicals, Textiles and Renewable Energy, Moi University, Eldoret, Kenya \\ ${ }^{3}$ Department of Quality Control and Quality Assurance, Product Development Directory, AgroWays Uganda Limited, \\ Jinja, Uganda \\ Correspondence should be addressed to Timothy Omara; prof.timo2018@gmail.com
}

Received 19 February 2020; Accepted 3 June 2020; Published 16 June 2020

Academic Editor: You-Cheng Hseu

Copyright (C) 2020 Timothy Omara. This is an open access article distributed under the Creative Commons Attribution License, which permits unrestricted use, distribution, and reproduction in any medium, provided the original work is properly cited.

\begin{abstract}
Snake envenomation is one of the neglected tropical diseases which has left an intolerable death toll and severe socioeconomic losses in Kenya. In a continued effort to identify some antiophidic East African botanical species, this study generated ethnobotanical information on antivenom plants reported in Kenya, with a view to identify potential species which could be subjected to in vitro and clinical studies for possible development into antivenoms. Data retrieved through searches done in multidisciplinary databases (Scopus, Web of Science, PubMed, Science Direct, Google Scholar, and Scientific Electronic Library Online) indicated that 54 plant species belonging to 45 genera, distributed among 27 families, are used for the management of snakebites in Kenya. Most species belonged to the family Asteraceae (11\%), Malvaceae (11\%), Fabaceae (9\%), Annonaceae (6\%), Combretaceae (6\%), and Lamiaceae (6\%). The main growth habit of the species is as herbs (35\%), shrubs (33\%), and trees (28\%). Ethnomedicinal preparations used in treating snake poisons are usually from leaves $(48 \%)$, roots $(26 \%)$, and stem bark $(8 \%)$ through decoctions, infusions, powders, and juices which are applied topically or administered orally. The most frequently encountered species were Combretum collinum, Euclea divinorum, Fuerstia africana, Grewia fallax, Microglossa pyrifolia, Solanecio mannii, and Solanum incanum. Indigenous knowledge on medicinal antivenom therapy in Kenya is humongous, and therefore studies to isolate and evaluate the antivenom compounds in the claimed plants are required to enable their confident use in antivenom therapy alongside commercial antivenin sera.
\end{abstract}

\section{Introduction}

Envenomation by snakes is one of the major causes of deaths recorded worldwide and has been flagged by the World Health Organization as a neglected tropical disease [1]. Globally, more than 5.5 million snake envenomations are encountered yearly, 2 million victims of which succumb to death while 0.4 million acquire permanent disability $[1,2]$. Up to 500,000 of these cases are reported annually in Africa [3-5]. Of these, more than 70,000 cases are from East Africa, and the situation has been exacerbated by climate change and deforestation which push snakes out of their natural habitats into the general population [6]. In 1971, 1972, and 1973, there were 89, 67, and 22 snakebite deaths recorded in Kenya [7]. In 1994, 151 snakebite cases were reported, with $19 \%$ being from venomous snakes [8]. Between 2007 and 2016, snakes injured 7,772 Kenyans, killing 614. Snakebite cases in the Baringo county alone in this period ranged between 300 and 500 cases per month $[9,10]$. The cases are typically high at the start of rainy seasons, when snakes come out of their shelter to hunt and breed [11]. Thus, 15 to 25 Kenyans die daily due to snake envenomation, and more than 100 others have their limbs amputated, causing them permanent disability [11]. Most bites are attributed to circumstantial stepping on the snakes by unprotected or barefooted victims [12] and snake ecology [13] while others are instituted by malevolent or drunk victims $[6,14]$. 
East Africa is a home to about 200 species of snakes of the over 400 species found in Africa. The puff adder (Bitis arietans), Gabon viper (Bitis gabonica), green or Jameson's mamba (Dendroaspis jamesoni), black mamba (Dendroaspis polylepis), forest cobra (Naja melanoleuca), and blacknecked spitting cobra (Naja naja nigricollis) are the most venomous serpents reported in Kenya $[15,16]$. Puff adders are the main envenoming serpents in Kenya for the fact that they are nocturnal and naturally well camouflaged. Their venoms are potently cytotoxic, causing severe pain, swelling, and blistering and in many cases are accompanied by severe tissue damage [6]. The black-necked spitting cobra is another common species which usually spits its venom into the eyes of the victims [6].

In its move to revise the Wildlife Conservation and Management Act 2013, the Kenya Wildlife Service noted that compensation claims for venomous snakebites accounted for $81 \%$ of all human-wildlife conflict claims [17]. These claims accumulated to billions of Kenya shillings over the years, prodding the Tourism and Wildlife ministry to declare the situation a crisis that threatens a bankrupt country. The burden led to the ousting of snakebites from the zoological list of compensable human-wildlife conflict claims $[6,17]$. The hot spots in Kenya with serious reports of snake envenomation include Baringo, Tharaka-Nithi, Taita Taveta, Kilifi, Kitui, Wajir, Garissa, Machakos, Marsabit, Isiolo, and Makueni [11, 16-19].

Antivenom sera is the only credited treatment for the management of snake envenomation [14, 20-22]. Unfortunately, they are associated with various side effects and may only be effective if administered within 30 minutes to 6 hours of the snakebite. Thus, the barriers to solving the menace of snakebites in Kenya range from poor road networks, fragmented records, and lack of public health education to the absence of antivenom and poor antivenom preservation facilities in health centres $[9,16,19,23]$. Lack of antivenom sera has been reported globally, and several attempts have been made to develop snake venom antagonists from other sources $[24,25]$ to supplement those derived from horses. In the East African case, some studies indicated that some antivenom sera on the market were ineffective against some medically important snake venoms $[15,26]$. Thus, up to $85 \%$ of Kenyan snakebite victims seek treatment from traditional medicine practitioners or use rudimentary means to eliminate the venom $[17,27]$. The current study gives an overview of traditional management of snake envenomation in Kenya, utilizing medicinal plants.

\section{Methodology}

Relevant literature pertaining to snakes, snakebites, and their management using medicinal plants in Kenya were sourced from Scopus, Web of Science Core Collection, PubMed, Science Direct, Google Scholar, and Scientific Electronic Library Online from November 2019 to January 2020, following procedures used in previous studies [28, 29]. The main search words used were snakebite, snake envenomation, vegetal, traditional medicine, ethnobotany, alternative medicine, ethnopharmacology, antivenom, antivenin, antiophidian, antitoxin, antidote, and Kenya. The search was performed independently in all the databases. The study databases included original articles published in peerreviewed journals, books, thesis, dissertations, patents, and other reports covering antivenin plants, dated until January 2020. All publishing years were considered in this narrative review, and articles with information on snakes, snakebites, or medicinal plants in Kenya were given the utmost priority.

Thus, references contained within the returned results were assessed concerning their inclusion in this study, and further searches were carried out at the Google search engine using more general search terms, to broaden the search as follows: words such as snake, plants, plant extract, vegetal, vegetal species, vegetal extract, traditional medicine, alternative medicine, complementary therapy, natural medicine, ethnopharmacology, ethnobotany, herbal medicine, herb, herbs, decoction, infusion, macerate, envenomation, nyoka (Swahili word for snake), snakebite, venom, antivenin, antivenom, and Kenya. The last search was done on 20 January 2020. The search outputs were saved where possible on databases, and the author received notification of any new searches meeting the search criteria from Science Direct, Scopus, and Google Scholar.

The scientific names of the plants listed were vetted in botanical databases: the Plant List [30], International Plant Names Index [31], NCBI taxonomy browser [32], and Tropicos [33], where a given species was considered as a distinct species in different reports, and the nomenclature as per the botanical databases took precedence. The families, local names (Luo, Kamba, Kikuyu, Markweta, Massai, and Swahili), growth habit, part (s) used, preparation, and administration mode were captured.

\section{Results and Discussion}

Only articles in English with information on antivenom plants or therapy were considered.

3.1. Perceptions about Snakes, Snakebites, and Antivenin Plants Used in Rural Kenya. From the information retrieved, it is clear that the local communities in Kenya are aware of snakebites and have different perceptions about snakes. The beliefs appear to be tribe related, and include snakes "can protect and are signs of fortune" among the Luo or "are connected to witchcraft" in most communities [11, 34-36]. The Luo for example believes that the sacred snake (Omieri) which lives in Lake Victoria (Nyanza) often surface in times of drought to "summon" the rains [35]. Among the Samia, the serpents are treated as gods, and some residents pray to them for prosperity of their families and businesses [36].

Most Kenyans know that their current social conditions such as chronic poverty, sleeping in thatched and brickwalled houses, and occupation such as cultivation, hunting, and herding cattle increase the chances of getting bitten by a snake $[12,14,18]$. Snakebites are always treated as exigencies, and the economic implications are perceived to be high due to the cost of transport to traditional healers or health facilities, the care needed by the victims, enforced 
borrowing, loss of legs, arms, income, and time, and sometimes death $[14,16]$.

This study retrieved 54 plant species from 45 genera belonging to 27 botanical families used in antivenin therapy in Kenya (Table 1). The common families were Asteraceae (11\%), Malvaceae (11\%), Fabaceae (9\%), Annonaceae (6\%), Combretaceae (6\%), and Lamiaceae (6\%) (Figure 1).

Most families encountered have been reported to have a potential for treating or avoiding snakebites in other countries. Apocynaceae, Asteraceae, Convolvulaceae, Fabaceae, and Myricaceae were cited in Uganda, Tanzania, Pakistan, Ethiopia, Djibouti, and Nigeria [28, 51-55]. Acanthaceae, Apocynaceae, Asteraceae, Euphorbiaceae, Fabaceae, Rubiaceae, and Rutaceae were reported in Bangladesh [56, 57], Central America [58], and India [59].

\subsection{Growth Habit, Parts Used, Preparation, and Adminis-} tration Methods of Antivenin Plants Used in Rural Kenya. The use of plants for treatment of snakebites is not novel in rural communities, and cases handled using antivenin plants rarely record victims succumbing to death [57, 60, 61]. Antivenom plants used in Kenya are majorly herbs (35\%), shrubs (33\%), and trees (28\%), and the commonly used plant parts are leaves $(48 \%)$, roots $(26 \%)$, and stem bark $(8 \%)$ (Figures 2 and 3). The regular use of roots and leaves in antivenom preparations is a characteristic feature of traditional antivenom therapy [40, 52, 62, 63], and no wonder some of these plants are named "snakeroot" in some rural communities [64]. Comparatively, embryonal plant parts such as fruits, seeds, buds, bulbs, and flowers which have reputation for accumulating bioactive compounds are less frequently utilized, concordant with the reports from other countries [28, 52]. Antivenom preparations are often decoctions, infusions, or poultices applied at the point of snakebite (topically) or ingested orally.

In this study, it was noted that few plant species are used against snakebites simultaneously in different locations. This could probably be attributed to the abundant distribution of the analogue active substances among the vegetal species, especially those from the family Asteraceae and Fabaceae. Some of the plants listed are also used for killing, wading off, or discouraging snakes from reaching human and livestock abodes. In most instances, the plants produce pungent odours which cause discomfort and disorientation to snakes when they slither over them. For example, the leaf sap of Sansevieria intermedia (locally known as Sorogat) is used as a bait to kill snakes [44]. In addition, maintaining a container of water some distance away from the house has been reported for dissuading snakes $[11,12,65]$. Burning of materials such as a piece of cloth has also been noted to discourage snakes [65], similar to tyre burning reported among the Lango of Uganda by Omara et al. [28].

Nearly, all the plants identified in this review are employed for the treatment of various ailments in Kenya and in other countries. For example, Bidens pilosa L. either as a whole plant or the different parts has been reported to be useful in the treatment of more than 40 disorders including inflammation, immunological disorders, digestive disorders, infectious diseases, cancer, metabolic syndrome, and wounds $[67,68]$. Such plants tend to be used in different communities for treating snakebites and there can be a justification of their efficacy. On the other hand, some of the antivenom plants cited tend to exhibit toxicity. For example, Catharanthus roseus (L.) G. Don has neurotoxic alkaloids, especially vincristine [68]. Vincristine and vinblastine are highly toxic antimitotics that block mitosis in the metaphase after binding to the microtubules [70]. Side effects such as myelosuppression, alopecia, abdominal cramps, constipation, nausea, paralytic ileus, ulcerations of the mouth, hepatocellular damage, kidney impairment, pulmonary fibrosis, urinary retention, amenorrhoea, azoospermia, orthostatic hypotension, and hypertension [71] have been reported for anticancer drugs vincristine and vinblastine derived from this plant. This observation explains in part, why some antivenom preparations in Kenya are applied topically or ingested in small amounts. Fortuitously, topical application is a better approach for reducing the local action of the venoms at the bitten sites [28].

3.3. Treatment of Snakebites. Antivenom therapy in rural Kenya usually involves monopreparations of plant extracts, while in a few cases, mixtures of different plant species and parts are used to prepare the antidotes. Some plants are used for treating envenomation by specific snakes. For example, Conyza sumatrensis (Retz.) E. Walker leaf infusion is used for management of puff adder bites [14, 34]. Maesa lanceolata Forssk. root bark decoction is then administered as a followup for such bites. Use of black stone (viper stone) has been cited in some parts of Kenya [9, 12, 36, 72]. The carbonized material (a piece of processed bone from a cow's thigh bone) is placed on the bite where it attaches and "sucks out" the venom. The stone, known as ekina erienjukha or ekina emari in the local Kisamia dialect, can be used several times for different victims and also alongside other treatment options, provided it is sterilized in boiling water for at least 15 minutes and then soaked in milk for two hours to neutralize it [36].

Among the Luo, oral administration of egg yolk and albumin prior to treatment was recorded [14]. In some communities, mystical therapies have been reported [27]. For instance, the snake "teeth" are crushed and mixed with a powder of burnt Opilia amentacea roots and applied to the bite. Other practices such as burning matchstick at the site of the bite, application of vaseline and tourniquets (or clothes impregnated with charcoal), and pouring paraffin and cold water on the bite have been documented [16]. Direct sucking of the venom from the bitten site has been also been cited [73]. Generally, incisions are made around the bite and herbal remedies are applied on the wound site. Antidotes are administered not later than half an hour after the bite and are usually accompanied by solace and advice to the victims [14]. In some instances, traditional healers with spiritual herbal skills may at their discretion invoke spiritual healings [14].

3.4. Knowledge Dynamics of Antivenin Therapy in Kenya. Information on antivenom plants and therapy is usually acquired and passed on orally from the elders to the young 
TABle 1: Antivenin plants used across Kenyan communities.

\begin{tabular}{|c|c|c|c|c|c|c|}
\hline Plant family & Botanical name & Local name & Part used & $\begin{array}{l}\text { Growth } \\
\text { habit }\end{array}$ & $\begin{array}{l}\text { Mode of preparation/ } \\
\text { administration }\end{array}$ & Authors \\
\hline & Justicia betonica L. & Shikuduli & Leaves & Herb & Infusion drunk & {$[37]$} \\
\hline Acanthaceae & $\begin{array}{l}\text { Justicia calyculata } \\
\text { (Deflers.) T. Anders }\end{array}$ & $\begin{array}{l}\text { Apiwo, piu piu } \\
\quad \text { (Luo) }\end{array}$ & Aerial parts & Herb & $\begin{array}{l}\text { Crushed and rubbed on the bite to } \\
\text { facilitate removal of the "snake's } \\
\text { fangs" }\end{array}$ & {$[14,34]$} \\
\hline \multirow[b]{2}{*}{ Amaryllidaceae } & Allium cepa L. & $\begin{array}{c}\text { Kitunguu } \\
\text { (Kamba) }\end{array}$ & $\begin{array}{l}\text { Leaves, } \\
\text { roots }\end{array}$ & Herb & Pounded and sap applied & {$[14]$} \\
\hline & $\begin{array}{l}\text { Ammocharis tinneana } \\
\text { (Kotschy \& Peyr.) } \\
\text { Milne-Redh }\end{array}$ & $\begin{array}{l}\text { Apap thwon pap, } \\
\text { rabwond otenga } \\
\text { (Luo) }\end{array}$ & Roots & Herb & $\begin{array}{l}\text { Sap used in preparation of an } \\
\text { alexiteric }\end{array}$ & {$[14,34]$} \\
\hline \multirow{3}{*}{ Annonaceae } & $\begin{array}{l}\text { Annona senegalensis } \\
\text { Pers. sp. senegalensis }\end{array}$ & $\begin{array}{l}\text { Obolo, obolobolo } \\
\text { (Luo) }\end{array}$ & Leaves & Tree & $\begin{array}{l}\text { Crushed and rubbed on the bite. } \\
\text { Some may be chewed, and the juice } \\
\text { swallowed }\end{array}$ & {$[14,34]$} \\
\hline & $\begin{array}{l}\text { Uvariodendron } \\
\text { anisatum Verdc. }\end{array}$ & Ndonga & $\begin{array}{c}\text { Whole } \\
\text { plant, leaves }\end{array}$ & Shrub & $\begin{array}{l}\text { Ashes applied to the bite, also used } \\
\text { for scorpion bites }\end{array}$ & {$[38,39]$} \\
\hline & Uvaria scheffleri Diels & $\begin{array}{l}\text { Mukukuma } \\
\text { (Kamba) }\end{array}$ & Root, leaves & Shrub & $\begin{array}{l}\text { Dried in the sun, pounded, and } \\
\text { powder applied }\end{array}$ & {$[14]$} \\
\hline Apiaceae & $\begin{array}{c}\text { Steganotaenia araliacea } \\
\text { Hochst. }\end{array}$ & $\begin{array}{c}\text { Muvuavui, } \\
\text { kivuavui (Kamba) }\end{array}$ & Roots & Shrub & $\begin{array}{l}\text { Burnt into charcoal, crushed into } \\
\text { powder, and applied on the bite }\end{array}$ & {$[14,40]$} \\
\hline \multirow{2}{*}{ Apocynaceae } & Carissa spinarum L. & Mukawa (Kamba) & Leaves & Shrub & $\begin{array}{l}\text { Used for treatment and has snake } \\
\text { repellent activity }\end{array}$ & {$[41]$} \\
\hline & $\begin{array}{l}\text { Catharanthus roseus } \\
\text { (L.) G. Don }\end{array}$ & Olubinu & Leaves & Herb & Infusion drunk & {$[37]$} \\
\hline \multirow[b]{2}{*}{ Asparagaceae } & Sansevieria kirkii Baker & $\begin{array}{l}\text { No local name } \\
\text { given }\end{array}$ & Leaves & Herb & Sap applied on the bite wound & {$[40]$} \\
\hline & $\begin{array}{l}\text { Sansevieria parva } \\
\text { N.E.Br. }\end{array}$ & $\begin{array}{l}\text { Twoch bungu } \\
\text { (Luo) }\end{array}$ & Leaves & Herb & Sap applied on the bite wound & {$[14,34]$} \\
\hline \multirow{6}{*}{ Asteraceae } & Bidens pilosa $\mathrm{L}$. & $\begin{array}{l}\text { Nyanyiek mon, } \\
\text { onyiego (Luo) }\end{array}$ & Leaves & Herb & $\begin{array}{l}\text { Crushed and rubbed on fresh cuts as } \\
\text { an astringent, snake bite antidote, } \\
\text { and antiseptic }\end{array}$ & {$[14,34]$} \\
\hline & $\begin{array}{l}\text { Conyza sumatrensis } \\
\text { (Retz.) E. Walker }\end{array}$ & $\begin{array}{l}\text { Yadh asere, yadh } \\
\text { tong' (Luo) }\end{array}$ & Leaves & Herb & Infusion drunk for puff adder bites & {$[14,34]$} \\
\hline & $\begin{array}{l}\text { Solanecio mannii } \\
\text { (Hook. f) C. Jeffrey }\end{array}$ & $\begin{array}{l}\text { Maroo, marowo } \\
\text { (Luo), livokho }\end{array}$ & Leaves & Shrub & $\begin{array}{c}\text { Crushed or chewed leaves rubbed } \\
\text { onto the bite }\end{array}$ & {$[14,34,37]$} \\
\hline & Tagetes minuta L. & $\begin{array}{l}\text { Muvangi } \\
\text { (Kamba) }\end{array}$ & Leaves & Herb & $\begin{array}{l}\text { Crushed, soaked in water, \& } \\
\text { infusion applied on bite }\end{array}$ & {$[14]$} \\
\hline & $\begin{array}{l}\text { Tithonia diversifolia } \\
\text { (Hemsl.) A. Gray. }\end{array}$ & $\begin{array}{l}\text { Maua madongo, } \\
\text { akech (Luo), mula } \\
\text { (Kamba) }\end{array}$ & Leaves & Shrub & Infusion administered orally & {$[14,34]$} \\
\hline & $\begin{array}{l}\text { Vernonia glabra (Steez) } \\
\text { Vatke }\end{array}$ & Olusia (Luo) & Leaves & Herb & $\begin{array}{l}\text { Leaf ash or crushed leaves rubbed } \\
\text { onto scarifications around the bite }\end{array}$ & {$[14,34]$} \\
\hline Bignoniaceae & $\begin{array}{l}\text { Markhamia lutea } \\
\text { (Benth.) K. Schum }\end{array}$ & $\begin{array}{l}\text { Lusiola, } \\
\text { shisimbali }\end{array}$ & Leaves & Tree & $\begin{array}{l}\text { Fresh leaf infusion drunk and used } \\
\text { for cleaning snake bite wounds }\end{array}$ & [37] \\
\hline Burseraceae & $\begin{array}{l}\text { Commiphora africana } \\
\text { (A. Rich.) Endl. }\end{array}$ & Osilalei & Bark & Tree & Chewed & {$[42]$} \\
\hline \multirow{3}{*}{ Combretaceae } & $\begin{array}{l}\text { Combretum collinum } \\
\text { Fresen }\end{array}$ & Adugo (Luo) & Roots & Tree & $\begin{array}{c}\text { For treatments effected by } \\
\text { scarification }\end{array}$ & {$[14,34,40]$} \\
\hline & $\begin{array}{l}\text { Combretum molle G. } \\
\text { Don }\end{array}$ & $\begin{array}{l}\text { Muama, kiama } \\
\text { (Kamba) }\end{array}$ & Bark, roots & Tree & $\begin{array}{c}\text { Infusion drunk; } 2 \text { glasses two times } \\
\text { a day }\end{array}$ & {$[14]$} \\
\hline & $\begin{array}{l}\text { Combretum padoides } \\
\text { Engl. \& Diels }\end{array}$ & $\begin{array}{c}\text { No local name } \\
\text { given }\end{array}$ & Leaves & Tree & $\begin{array}{c}\text { Crushed leaves are applied on the } \\
\text { bite }\end{array}$ & {$[43]$} \\
\hline Convolvulaceae & $\begin{array}{l}\text { Dichondra repens J.R. } \\
\text { Forst. \& G. Forst. }\end{array}$ & $\begin{array}{l}\text { No Luo name } \\
\text { given }\end{array}$ & Leaves & Herb & $\begin{array}{l}\text { Rubbed on bite to "remove snake } \\
\text { fangs" }\end{array}$ & {$[14,34]$} \\
\hline Ebenaceae & $\begin{array}{l}\text { Euclea divinorum } \\
\text { Hiern }\end{array}$ & $\begin{array}{c}\text { Uswet } \\
\text { (Markweta) }\end{array}$ & Bark & Tree & $\begin{array}{c}\text { Crushed \& applied on incision } \\
\text { made on the bite area. Sometimes } \\
\text { used with of Gardenia volkensii and } \\
\text { Plectranthus barbatus. }\end{array}$ & [44-46] \\
\hline
\end{tabular}


TABle 1: Continued.

\begin{tabular}{|c|c|c|c|c|c|c|}
\hline Plant family & Botanical name & Local name & Part used & $\begin{array}{c}\text { Growth } \\
\text { habit }\end{array}$ & $\begin{array}{l}\text { Mode of preparation/ } \\
\text { administration }\end{array}$ & Authors \\
\hline Euphorbiaceae & Tragia brevipes Pax. & $\begin{array}{l}\text { Kimelei ne } \\
\text { mining } \\
\text { (Markweta) }\end{array}$ & Roots & Shrub & $\begin{array}{l}\text { Crushed and applied on incisions } \\
\text { made on the bitten area }\end{array}$ & {$[44,46]$} \\
\hline \multirow{5}{*}{ Fabaceae } & $\begin{array}{c}\text { Entada leptostachya } \\
\text { Harms }\end{array}$ & Mwaitha (Kamba) & Stem & Tree & $\begin{array}{l}\text { Stem crushed, sap squeezed out, } \\
\text { and applied on the bite }\end{array}$ & {$[14]$} \\
\hline & Erythrina excelsa Baker & $\begin{array}{l}\text { Roko, yuoma } \\
\quad \text { (Luo) }\end{array}$ & Bark & Tree & Sap is used as an antidote & {$[14,34]$} \\
\hline & Erythrina abyssinica & $\begin{array}{l}\text { Omutembe } \\
\text { (Kuria), muhuti } \\
\text { (Kikuyu) }\end{array}$ & Bark & Tree & Sap is used as an antidote & {$[40]$} \\
\hline & $\begin{array}{c}\text { Indigofera circinella } \\
\text { Baker } \mathrm{f} .\end{array}$ & Odolo (Luo) & Leaves & Herb & $\begin{array}{l}\text { Poultice chewed and pasted on the } \\
\text { bite }\end{array}$ & {$[14,34]$} \\
\hline & $\begin{array}{l}\text { Senna siamea (Lam.) } \\
\text { Irwin et Barnaby }\end{array}$ & $\begin{array}{c}\text { Ndege owinu, } \\
\text { oyieko (Luo) }\end{array}$ & Roots & Tree & $\begin{array}{l}\text { Used with Zanthoxylum chalybeum } \\
\text { Engl. roots }\end{array}$ & {$[14]$} \\
\hline \multirow{3}{*}{ Lamiaceae } & $\begin{array}{l}\text { Fuerstia africana T.C.E. } \\
\text { Fr. }\end{array}$ & $\begin{array}{l}\text { Abunga-useke, } \\
\text { aremo (Luo) }\end{array}$ & Leaves & Herb & Crushed and filtered infusion drank & {$[14,34,47]$} \\
\hline & $\begin{array}{l}\text { Hyptis pectinata }(\mathrm{L} .) \\
\text { Poit }\end{array}$ & Not specified & Leaves & Herb & $\begin{array}{l}\text { Infusion with Corchorus trilocularis } \\
\text { L. is dropped or sprinkled into the } \\
\text { eye to neutralize venom ejected into } \\
\text { it by black-necked spitting cobra. } \\
\text { After, the victim is scarified on the } \\
\text { hind torso. Claims of intense pain, } \\
\text { temporary blindness, and watery } \\
\text { eyes were linked to this type of } \\
\text { envenomation. }\end{array}$ & {$[14]$} \\
\hline & $\begin{array}{c}\text { Plectranthus barbatus } \\
\text { Andrews }\end{array}$ & $\begin{array}{l}\text { Kan'gurwet } \\
\text { (Markweta) }\end{array}$ & Leaves & Herb & $\begin{array}{l}\text { Mixed with those of Gardenia } \\
\text { volkensii and Euclea divinorum. The } \\
\text { powder mixture is then applied on } \\
\text { incisions made on the bitten area. }\end{array}$ & {$[46]$} \\
\hline \multirow{6}{*}{ Malvaceae } & $\begin{array}{c}\text { Corchorus trilocularis } \\
\text { L. }\end{array}$ & Apoth (Luo) & Leaves & Herb & $\begin{array}{l}\text { Infusion with Hyptis pectinata is } \\
\text { dropped or sprinkled into the eye to } \\
\text { neutralize snake venom ejected into } \\
\text { the human eye }\end{array}$ & {$[14,34]$} \\
\hline & Grewia bicolor Juss. & $\begin{array}{l}\text { Esiteti (Massai), } \\
\text { mulawa (Kamba) }\end{array}$ & Roots & Shrub & Infusion drunk & {$[40,42]$} \\
\hline & Grewia damine Gaertn. & Ositeti & $\begin{array}{l}\text { Bark, } \\
\text { branch, } \\
\text { fruits, roots, } \\
\text { stem }\end{array}$ & Shrub & Not specified & {$[48]$} \\
\hline & $\begin{array}{l}\text { Grewia fallax } \mathrm{K} . \\
\text { Schum. }\end{array}$ & $\begin{array}{l}\text { Powo (Luo), ilawa } \\
\text { (Kamba) }\end{array}$ & Leaves, bark & Shrub & $\begin{array}{l}\text { Used in cooking envenomed carcass } \\
\text { to prevent secondary poisoning. } \\
\text { Bitten livestock are drenched with a } \\
\text { decoction. Mucilaginous crushed } \\
\text { leaves used to wipe the bitten area. }\end{array}$ & {$[14,34,40]$} \\
\hline & \multirow{2}{*}{$\begin{array}{l}\text { Grewia truncate Mast. } \\
\text { Triumfetta rhomboidea } \\
\text { Jacq. }\end{array}$} & Not given & Leaves & Shrub & Not specified & {$[40]$} \\
\hline & & $\begin{array}{l}\text { Muinda nguue } \\
\text { (Kamba) }\end{array}$ & Roots & Herb & $\begin{array}{l}\text { Crushed, aqueous infusion applied } \\
\text { on bite area }\end{array}$ & {$[14]$} \\
\hline Musaceae & $\begin{array}{l}\text { Ensete edule (J. F. } \\
\text { Gmel.) Horan }\end{array}$ & Kitembe (Luo) & Stem & Herb & $\begin{array}{c}\begin{array}{l}\text { Fresh stem sap is wiped onto the } \\
\text { bite }\end{array} \\
\end{array}$ & {$[14,34]$} \\
\hline Myricaceae & $\begin{array}{l}\text { Maesa lanceolata } \\
\text { Forssk. }\end{array}$ & Katera (Luo) & Roots & Tree & $\begin{array}{l}\text { Decoction administered as follow- } \\
\text { up treatment for puff adder bites }\end{array}$ & {$[14,34]$} \\
\hline Opiliaceae & Opilia amentacea Roxb. & $\begin{array}{l}\text { Mutonga } \\
\text { (Kamba) }\end{array}$ & Roots & Climber & $\begin{array}{l}\text { Roots burnt into charcoal, crushed } \\
\text { into powder, mixed with crushed } \\
\text { snake teeth, and applied to the bite }\end{array}$ & {$[14]$} \\
\hline Phytolaccaceae & $\begin{array}{l}\text { Phytolacca dodecandra } \\
\text { L. Hiern }\end{array}$ & Kupsogotit & $\begin{array}{l}\text { Leaves, } \\
\text { fruits }\end{array}$ & Shrub & Burnt, chewed & {$[45]$} \\
\hline Polygalaceae & $\begin{array}{c}\text { Securidaca } \\
\text { longepedunculata }\end{array}$ & & $\begin{array}{c}\text { Not } \\
\text { specified }\end{array}$ & Shrub & Not specified & {$[49]$} \\
\hline
\end{tabular}


TABle 1: Continued.

\begin{tabular}{|c|c|c|c|c|c|c|}
\hline Plant family & Botanical name & Local name & Part used & $\begin{array}{l}\text { Growth } \\
\text { habit }\end{array}$ & $\begin{array}{l}\text { Mode of preparation/ } \\
\text { administration }\end{array}$ & Authors \\
\hline Pteridaceae & $\begin{array}{l}\text { Pellaea viridis (Forssk.) } \\
\text { Prantl. }\end{array}$ & $\begin{array}{l}\text { No Luo name } \\
\text { given }\end{array}$ & Leaves & Herb & Pulped and rubbed on the bite & {$[14,34]$} \\
\hline Rhamnaceae & $\begin{array}{l}\text { Ziziphus mucronata } \\
\text { Willd. }\end{array}$ & Oloilalei & Roots & Shrub & Infusion drunk & {$[42]$} \\
\hline \multirow[t]{2}{*}{ Rubiaceae } & Gardenia volkensii & $\begin{array}{c}\text { Mogilio } \\
\text { (Markweta) }\end{array}$ & Leaves & Tree & $\begin{array}{l}\text { Mixed with those of Plectranthus } \\
\text { barbatus and Euclea divinorum. The } \\
\text { powder mixture is then applied on } \\
\text { incisions made on the bitten area. }\end{array}$ & {$[46]$} \\
\hline & $\begin{array}{l}\text { Hymenodictyon } \\
\text { parvifolium }\end{array}$ & Mulinditi & Leaves & Shrub & Crushed and infusion drunk & {$[50]$} \\
\hline \multirow{2}{*}{ Rutaceae } & $\begin{array}{l}\text { Toddalia asiatica }(\mathrm{L}) \\
\text { Lam. }\end{array}$ & Mururue (kikuyu) & Root bark & Liana & Infusion & {$[40]$} \\
\hline & $\begin{array}{l}\text { Zanthoxylum } \\
\text { chalybeum Engl. }\end{array}$ & Oloisuki (massai) & Roots & Tree & $\begin{array}{l}\text { Used with the roots of Senna siamea } \\
\text { (Lam.) Irwin et Barnaby }\end{array}$ & {$[14]$} \\
\hline \multirow[t]{2}{*}{ Solanaceae } & Solanum incanum L. & $\begin{array}{l}\text { Mutongu } \\
\text { (Kamba) }\end{array}$ & $\begin{array}{l}\text { Leaves, } \\
\text { stem, fruit }\end{array}$ & Shrub & $\begin{array}{l}\text { Leaves chewed and applied at the } \\
\text { bite. Stem/fruits sliced, sun dried, } \\
\text { pounded, and powder applied. The } \\
\text { sap of the fruits may also be directly } \\
\text { applied. }\end{array}$ & {$[14,40,42]$} \\
\hline & $\begin{array}{l}\text { Solanum micranthum } \\
\text { Schltdl. }\end{array}$ & Sigowet & Root, fruit & Shrub & $\begin{array}{l}\text { Treats snake, cat, or dog bite. Burnt } \\
\text { or boiled and infusion taken }\end{array}$ & {$[45]$} \\
\hline Velloziaceae & Xerophyta spekei Baker & Kianduri & Whole plant & Shrub & Ashes applied to the bite & {$[38]$} \\
\hline
\end{tabular}

Decoction: water extraction by boiling of plant material; infusion: the plant material is added to hot water, steeped for few minutes, and taken as tea.

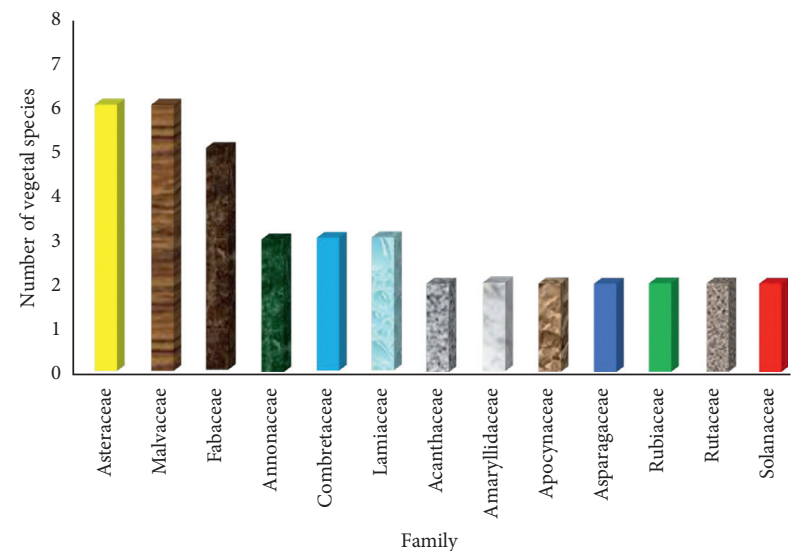

FIgURE 1: Major families from which vegetal antivenoms are obtained in rural Kenya.

(apprenticeships from relatives) $[14,50]$ as is the case with other African countries [28, 74]. Others acquire knowledge through own observations, formal training, or are inducted by mobile herbal practitioners [49]. However, expert healers are either spirit inspired [14] or had ancestral induction through dreams [50].

Most antivenom plants utilized by traditional healers in Kenya have not been fully documented despite the obvious risk of their disappearance owing to threats such as deforestation, overexploitation, and death of traditional healers with knowledge of the plants $[14,75]$. This is confounded by the fact that traditional medicine is usually a guarded family secret, and as reported in other African countries $[14,75,76]$, children are not always willing to inherit the art



FIgURE 2: Life forms of the antivenom plants used in rural communities of Kenya.

because they spend most of their youthful years at school $[14,78]$. Most of the antivenom plant species are indigenous (wild and uncultivated), though some such as Allium cepa, Tagetes minuta, Senna siamea, and Tithonia diversifolia are naturalized exotic species.

\section{Future Perspectives}

In a view to capture snakebite records, Kenyan health authorities suggested that traditional medicine should be integrated with modern medicine since the former is usually the first point of contact by snakebite victims and is usually the most trusted in their societies [14, 27]. The Kenya Snakebite Research and Intervention Centre predicts to produce East Africa's first antivenom medication within five 


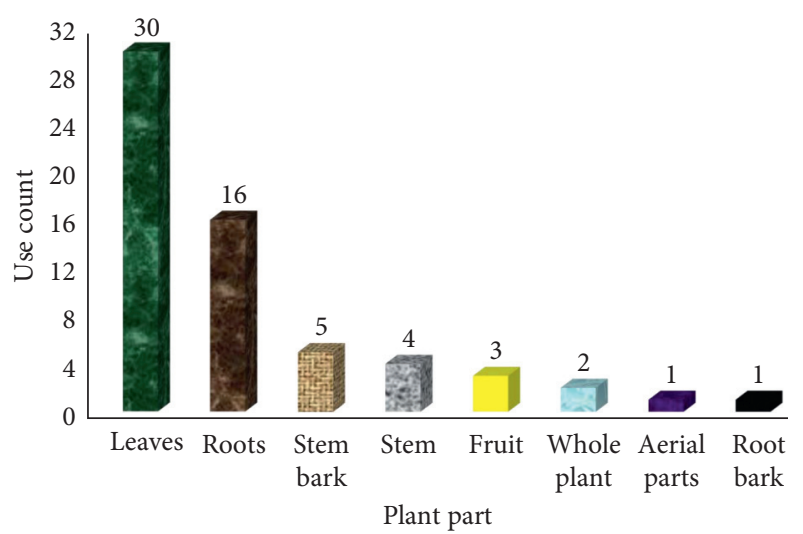

FIGURE 3: Different parts of antivenom plants used for management of snakebites in Kenya.

years at a cost about $30 \%$ of the currently imported antisera [79]. Kenya currently extracts venoms from snakes, which are transported to South Africa for manufacturing antivenoms [17]. To reduce the menace of snakebites, the Kenyan government has reached out to train health workers in management of snakebites as well as the local community [80]. It has also keyed in an initiative to establish snake parks notably the Mwingi plant sanctuary in the Kitui county, the Nairobi snake park in Nairobi, the Lake Baringo reptile park, and Dr. Richard Leakey's snake park in the Baringo county. These are expected to reduce the snake population as well as boost tourism industry [81]. Exploration of antivenin plants for their efficacy in snakebite therapy could be one of the interventions in management of snakebites, as interfacing with these serpents are inevitable and treatment of snakebites cannot be managed by commercial antivenins alone.

\section{Conclusion}

The inventory of plants utilized by Kenyan communities present a considerable potential for treatment of snake envenomation and dissuading snakes. More ethnobotanical surveys should be done in the uncovered areas, and health authorities need to devise means of collecting coherent data on snakebites in the country to enhance effective planning for management of the menace.

\section{Data Availability}

This is a review article, and no raw experimental data were collected. All data generated or analysed during this study are included in this published article.

\section{Conflicts of Interest}

The author declares that there are no conflicts of interest regarding the publication of this paper.

\section{Acknowledgments}

The author is grateful to the World Bank and the InterUniversity Council of East Africa (IUCEA) for the scholarship awarded to him through the Africa Centre of Excellence II in Phytochemicals, Textiles, and Renewable Energy (ACE II PTRE) at Moi University, Kenya, that prompted this ethnomedical communication. The author commends preceding authors for their fruitful quest for knowledge on medicinal plants utilized by rural communities of Kenya.

\section{References}

[1] WHO, Guidelines for the Production, Control and Regulation of Snake Antivenom Immunoglobulins, World Health Organization, Geneva, Switzerland, 2010.

[2] J. M. Gutiérrez, D. A. Warrel, D. J. Williams et al., "The need for full integration of snakebite envenoming within a global strategy to combat the neglected tropical diseases: the way forward," PLoS Neglected Tropical Diseases, vol. 7, no. 6, Article ID e2126, 2013.

[3] J. P. Chippaux, "Snake-bites: appraisal of the global situation," Bulletin of the World Health Organization, vol. 76, no. 5, pp. 515-524, 1998.

[4] D. A. Warrell and C. Arnett, "The importance of bites by the saw-scaled or carpet viper (Echis carinatus): epidemiological studies in Nigeria and a review of the world literature," Acta Tropica, vol. 33, no. 4, pp. 307-341, 1976.

[5] R. D. G. Theakston, D. A. Warrell, and E. Griffiths, "Report of a WHO workshop on the standardization and control of antivenoms," Toxicon, vol. 41, no. 5, pp. 541-557, 2003.

[6] Wildlife Direct, Combating Snakebite in Kenya, Wildlife Direct, Nairobi, Kenya, 2019, https://wildlifedirect.org/ portfolio-items/combating-snakebite-in-kenya/.

[7] B. S. Mbindyo and G. B. A. Okello, Common Venomous Bites and Stings in Kenya, The Health Education Division and Audio-Visual Aids Centre, Nairobi, Kenya, 1979.

[8] R. W. Snow, R. Bronzan, T. Roques, C. Nyamawi, S. Murphy, and K. Marsh, "The prevalence and morbidity of snake bite and treatment-seeking behaviour among a rural Kenyan population," Annals of Tropical Medicine \& Parasitology, vol. 88, no. 6, pp. 665-671, 1994.

[9] A. Langat and A. I Lazeera, "For rural Kenyans, treating snakebites is an uphill struggle," 2019, https://www.aljazeera. com/indepth/features/rural-kenyans-treating-snakebitesuphill-struggle-191001184310362.html.

[10] Baringo County Government: Health News, 2019, http:// www.baringo.go.ke/index.php?option $=$ com_content\&view $=$ article\&id=1757:reprieve-for-snake-bites-prone-areas-as-countyconducts-sensitization-forum\&catid=37\&Itemid $=188$.

[11] Daily Nation, Panic, Sorcery Claim after Snake Killed at Baringo Assembly, Daily Nation, Nairobi, Kenya, 2019, https://www. nation.co.ke/counties/marsabit/Snake-causes-panic-Baringoassembly/3444778-5342346-eupsvj/index.html.

[12] N. A. Nasio, "Snake bites: a forgotten menace in Kenya," International Journal of Scientific Research and Innovative Technology, vol. 3, no. 7, pp. 1-7, 2016.

[13] Y. Musah, E. P. K. Ameade, D. K. Attuquayefio, and L. H. Holbech, "Epidemiology, ecology and human perceptions of snakebites in a savanna community of northern Ghana," PLoS Neglected Tropical Diseases, vol. 13, no. 8, Article ID e0007221, 2019.

[14] B. O. Owuor and D. P. Kisangau, "Kenyan medicinal plants used as antivenin: a comparison of plant usage," Journal of Ethnobiology and Ethnomedicine, vol. 2, no. 1, p. 7, 2006. 
[15] R. A. Harrison, G. O. Oluoch, S. Ainsworth et al., "Preclinical antivenom-efficacy testing reveals potentially disturbing deficiencies of snakebite treatment capability in East Africa," PLoS Neglected Tropical Diseases, vol. 11, no. 10, Article ID e0005969, 2017.

[16] M. O. Okumu, M. N. Patel, F. R. Bhogayata et al., "Management and cost of snakebite injuries at a teaching and referral hospital in Western Kenya," F1000Research, vol. 8, p. 1588, 2019.

[17] Daily Nation, Why, in Kenya, A Snake Bite is Likely to Kill You, Daily Nation, Nairobi, Kenya, 2019, https://mobile. nation.co.ke/news/Why-in-Kenya-a-snake-bite-is-likely-tokill-you/1950946-5301852-10ep5uc/index.html.

[18] D. K. Kuria, "Venomous snake bite injuries at Kitui district hospital," Annals of African Surgery, vol. 10, no. 1, pp. 15-20, 2013.

[19] F. O. Ochola, M. O. Okumu, G. M. Muchemi, J. M. Mbaria, and J. K. Gikunju, "Epidemiology of snake bites in selected areas of Kenya," Pan African Medical Journal, vol. 29, p. 217, 2018.

[20] R. Wangoda, B. Watmon, and M. Kisige, "Snakebite management: experiences from Gulu regional hospital, Uganda," East and Central African Journal of Surgery, vol. 9, no. 1, pp. 1-5, 2004.

[21] Daily Monitor, Using Nature to Get Rid of Snakes and Their Venom, Daily Monitor, Kampala, Uganda, 2015, https://www. monitor.co.ug/Magazines/HealthLiving/Using-nature-toget-rid-of-snakes-and-their-venom/689846-2852038-78tprn/ index.html.

[22] B. Janardhan B, V. M. Shrikanth, K. K. Mirajkar, and S. S. More, "In vitro screening and evaluation of antivenom phytochemicals from Azima tetracantha Lam. leaves against Bungarus caeruleus and Vipera russelli," Journal of Venomous Animal Toxins Including Tropical Diseases, vol. 20, no. 1, p. 12, 2014.

[23] M. Kahenda, "Shortage of antivenom in baringo leave victims crying for medical aid," 2018, https://www.standardmedia.co. ke/article/2001294313/snake-bite-victims-at-risk-over-lackof-drugs.

[24] H. Zolfagharian and N. M. Dounighi, "Study on development of Vipera lebetina snake anti-venom in chicken egg yolk for passive immunization," Human Vaccines \& Immunotherapeutics, vol. 11, no. 11, pp. 2734-2739, 2015.

[25] R. A. Harrison, S. S. Hasson, M. Harmsen, G. D. Laing, K. Conrath, and R. D. G. Theakston, "Neutralisation of venom-induced haemorrhage by IgG from camels and llamas immunised with viper venom and also by endogenous, nonIgG components in camelid sera," Toxicon, vol. 47, no. 3, pp. 364-368, 2006.

[26] F. O. Ochola, M. O. Okumu, J. K. Gikunju, J. M. Mbaria, G. M. Muchemi, and J. G. Nderitu, "Neutralization of the lethality of the venom of Dendroaspis polylepis (black mamba) in mice by two polyvalent antivenoms used in Kenyan hospitals: results of a 2009-2011 study," Scientific African, vol. 5, Article ID e00118, 2019.

[27] M. Saya, "26 reported cases of snakebites in Baringo, shows study," 2019, https://www.the-star.co.ke/counties/rift-valley/ 2019-12-09-26-reported-cases-of-snakebites-in-baringoshows-study/.

[28] T. Omara, S. Kagoya, A. Openy et al., "Antivenin plants used for treatment of snakebites in Uganda: ethnobotanical reports and pharmacological evidences," Tropical Medicine and Health, vol. 48, no. 1, pp. 1-16, 2020.
[29] T. Omara, A. K. Kiprop, R. C. Ramkat et al., "Medicinal plants used in traditional management of cancer in Uganda: a review of ethnobotanical surveys, phytochemistry, and anticancer studies," Evidence-Based Complementary and Alternative Medicine, vol. 2020, Article ID 3529081, 26 pages, 2020.

[30] The Plant List, 2010, http://www.theplantlist.org/.

[31] International Plant Names Index, 1999, https://www.ipni.org/

[32] NCBI Taxonomy Browser, https://www.ncbi.nlm.nih.gov/ taxonomy.

[33] Tropicos, http://www.tropicos.org/.

[34] B. O. Owuor, B. A. Mulemi, and J. O. Kokwaro, "Indigenous snake bite remedies of the Luo of Western Kenya," Journal of Ethnobiology, vol. 25, no. 1, pp. 129-141, 2005.

[35] Worldwide Zoo Database, Lake Baringo Reptile Park, http:// www.wzd.cz/zoo/AF/KE/lake_baringo_reptile_park/ke_ kampi_ya_samaki_text01-eng.htm.

[36] KNA, Magic Stone that Treats Snake Bites, KNA, Reno, NV, USA, 2016, https://businesstoday.co.ke/magic-stone-thattreats-snake-bites/.

[37] J. O. Kokwaro, Medicinal Plants of East Africa, East African Literature Bureau, Nairobi, Kenya, 2nd edition, 1993.

[38] P. G. Kareru, G. M. Kenji, A. N. Gachanja, J. M. Keriko, and G. Mungai, "Traditional medicines among the Embu and Mbeere people of Kenya," African Journal of Traditional, Complementary and Alternative Medicine, vol. 4, no. 1, pp. 75-86, 2007.

[39] O. S. Adongo, "Medicinal plants of Chuka community in Tharaka Nithi County, Kenya and some of their selected essential elements," M.S. thesis, Kenyatta University, Nairobi, Kenya, 2013.

[40] J. O. Kokwaro, Medicinal Plants of East Africa, East Africa Education Publishers, Nairobi, Kenya, 1994.

[41] P. M. Maundu, B. Tengnèas, A. Birnie, and N. Muema, Useful Trees and Shrubs for Kenya, World Agroforestry Centre, Nairobi, Kenya, 2nd edition, 2005.

[42] G. Kigen, Z. Kamuren, E. Njiru, B. Wanjohi, and W. Kipkore, "Ethnomedical survey of the plants used by traditional healers in Narok County, Kenya," Evidence-Based Complementary and Alternative Medicine, vol. 2019, Article ID 8976937, 8 pages, 2019.

[43] Prota4U, Combretum Padoides Engl. \& Diels, https://www. prota4u.org/database/protav8.asp?g=pe\&p=Combretum + padoides+Engl.+\&+Diels.

[44] W. Kipkore, B. Wanjohi, H. Rono, and G. Kigen, "A study of the medicinal plants used by the Marakwet community in Kenya," Journal of Ethnobiology and Ethnomedicine, vol. 10, no. 1, p. 24, 2014.

[45] S. V. Okello, R. O. Nyunja, G. W. Netondo, and J. C. Onyango, "Ethnobotanical study of medicinal plants used by Sabaots of Mt. Elgon Kenya," African Journal of Traditional, Complementary and Alternative Medicine, vol. 7, no. 1, pp. 1-10, 2009.

[46] G. Kigen, F. Some, J. Kibosia et al., "Ethnomedicinal plants traditionally used by the Keiyo community in Elgeyo Marakwet County, Kenya," Journal of Biodiversity and Bioprospecting and Development, vol. 1, no. 3, p. 11, 2014.

[47] D. O. Okach, A. R. O. Nyunja, and G. Opande, "Phytochemical screening of some wild plants from Lamiaceae and their role in traditional medicine in Uriri District-Kenya," International Journal of Herbal Medicine, vol. 1, no. 5, pp. 135-143, 2013.

[48] J. Nankaya, J. Nampushi, S. Petenya, and H. Balslev, "Ethnomedicinal plants of the Loita Maasai of Kenya," 
Environment, Development and Sustainability, vol. 22, no. 3, pp. 2569-2589, 2020.

[49] J. India, "Efficacy of some medicinal plants used in various parts of Kenya in treating selected bacterial and fungal pathogens," M.S. thesis, Kenyatta University, Nairobi, Kenya, 2015.

[50] D. Kisangau, M. Kauti, R. Mwobobia, T. Kanui, and N. Musimba, "Traditional knowledge on use of medicinal plants in Kitui County, Kenya," International Journal of Ethnobiology \& Ethnomedicine, vol. 4, no. 1, pp. 1-10, 2017.

[51] C. K. Ruffo, "A survey of medicinal plants in Tabora region Tanzania," in Traditional Medicinal Plants, p. 391, Dar es Salaam University Press-Ministry of Health-Tanzania, Lushoto, Tanzania, 1991.

[52] A. Yirgu and J.-P. Chippaux, "Ethnomedicinal plants used for snakebite treatments in Ethiopia: a comprehensive overview," Journal of Venomous Animal and Toxins Including Tropical Diseases, vol. 25, 2019.

[53] A. Shah, R. Sarvat, S. Shoaib et al., "An ethnobotanical survey of medicinal plants used for the treatment of snakebite and scorpion sting among the people of Namal valley, Mianwali district, Punjab, Pakistan," Applied Ecology and Environmental Research, vol. 16, no. 1, pp. 111-143, 2018.

[54] A. Hassan-Abdallah, A. Merito, S. Hassan et al., "Medicinal plants and their uses by the people in the region of Randa, Djibouti," Journal of Ethnopharmacology, vol. 148, no. 2, pp. 701-713, 2013.

[55] M. Abd El-Ghani, "Traditional medicinal plants of Nigeria: an overview," Agriculture and Biology Journal of North America, vol. 7, pp. 220-247, 2016.

[56] F. M. Kadir, J. R. Karmoker, M. R. Alam, S. R. Jahan, S. Mahbub, and M. M. K. Mia, "Ethnopharmacological survey of medicinal plants used by traditional healers and indigenous people in Chittagong hill tracts, Bangladesh, for the treatment of snakebite," Evidence-Based Complementary and Alternative Medicine, vol. 2015, Article ID 871675, 23 pages, 2015.

[57] N. Hasan, N. K. Azam, N. Ahmed, and A. Hirashima, "A randomized ethnomedicinal survey of snakebite treatment in southwestern parts of Bangladesh," Journal of Traditonal and Complementary Medicine, vol. 6, no. 4, pp. 6337-6342, 2016.

[58] P. Giovannini and M.-J. R. Howes, "Medicinal plants used to treat snakebite in Central America: review and assessment of scientific evidence," Journal of Ethnopharmacology, vol. 199, pp. 240-256, 2017.

[59] S. J. U. Kumar, K. Chaitanya, A. J. Semotiuk, and V. Krishna, "Indigenous knowledge of medicinal plants used by ethnic communities of South India," Ethnobotany Research and Applications, vol. 18, pp. 1-112, 2019.

[60] R. Otero, R. Fonnegra, S. L. Jiménez et al., "Snakebites and ethnobotany in the northwest region of Colombia," Journal of Ethnopharmacology, vol. 71, no. 3, pp. 493-504, 2000.

[61] Forest Trends, Amazonian Tribe Shares the Secret of Treating Snake Bites, Forest Trends, Washington, DC, USA, 2017, https://www.forest-trends.org/blog/amazonian-tribe-secrettreating-snake-bites/.

[62] J. M. Watt and M. G. Breyer-Brandwijk, The Medicinal and Poisonous Plants of Southern and Eastern Africa, E. \& S. Livingstone Ltd., London, UK, 1962.

[63] S. V. Upasani, V. G. Beldar, A. U. Tatiya, M. S. Upasani, S. J. Surana, and D. S. Patil, "Ethnomedicinal plants used for snakebite in India: a brief overview," Integrative Medicine Research, vol. 6, no. 2, pp. 114-130, 2017.

[64] N. Taylor, "Snake root," in Encyclopaedia Britannica, Vol. 20, William Benton, Chicago, IL, USA, 1970.
[65] W. Nyabwa, "Alarm as snake population soars in Baringo as anti-venom runs out," 2015, https://citizentv.co.ke/lifestyle/ alarm-as-snake-population-soars-in-baringo-as-anti-venomruns-out-100645/.

[66] J. Muriithi, "Kirinyaga teacher accidentally burns her house while trying to kill a snake," 2019, https://citizentv.co.ke/news/ kirinyaga-teacher-accidentally-burns-her-house-while-tryingto-kill-a-snake-306638/?utm_source=relatedarticles\&utm_ medium=deeplinking\&utm_campaign=AlsoRead.

[67] C. Wiart, Medicinal Plants of Southeast Asia, Pelanduk, Selabgor Darul Ehsan, Malaysia, 2000.

[68] T. Dimo, J. Azay, P. V. Tan et al., "Effects of the aqueous and methylene chloride extracts of Bidens pilosa leaf on fructosehypertensive rats," Journal of Ethnopharmacology, vol. 76, no. 3, pp. 215-221, 2001.

[69] S. Nobili, D. Lippi, E. Witort et al., "Natural compounds for cancer treatment and prevention," Pharmacological Research, vol. 59, no. 6, pp. 365-378, 2009.

[70] M. A. Jordan and L. Wilson, "Microtubules as a target for anticancer drugs," Nature Reviews Cancer, vol. 4, no. 4, pp. 253-265, 2004.

[71] S. A. James, L. Bilbiss, and B. Y. Muhammad, "The effects of Catharanthus roseus (l) g. don 1838 aqueous leaf extract on some liver enzymes, serum proteins and vital organs," Science World Journal, vol. 2, no. 1, pp. 5-9, 2007.

[72] The East African, Mombasa Students Develop Stones to Treat Snake Bites, The East African, Arusha, Tanzania, 2015, https:// www.theeastafrican.co.ke/news/ea/Mombasa-students-developstones-to-treat-snake-bites/4552908-2901350-format-xhtml-15 uopym/index.html.

[73] B. Janardhan, V. M. Shrikanth, K. K. Mirajkar, and S. S. More, "In vitro anti-snake venom properties of Carisssa spinarum Linn leaf extracts," Journal of Herbs, Spices \& Medicinal Plants, vol. 21, no. 3, pp. 283-293, 2015.

[74] D. Wodah and A. Asase, "Ethnopharmacological use of plants by Sisala traditional healers in Northwest Ghana," Pharmaceutical Biology, vol. 50, no. 7, pp. 807-815, 2012.

[75] G. K. Kigen, H. K. Ronoh, W. K. Kipkore, and J. K.. Rotich, "Current trends of traditional herbal medicine practice in Kenya: a review," African Journal of Pharmacology and Therapeutics, vol. 2, no. 1, pp. 32-37, 2013.

[76] G. Anywar, H. Oryem-Origa, and M. M. Kamatenesi, "Wild plants used as nutraceuticals from Nebbi district, Uganda," European Journal of Medicinal Plants, vol. 4, no. 6, pp. 641660, 2014.

[77] G. Anywar, C. I. E. A. Van't Klooster, R. Byamukama et al., "Medicinal plants used in the treatment and prevention of malaria in Cegere sub-county, Northern Uganda," Ethnobotany Research and Applications, vol. 14, pp. 505-516, 2016.

[78] R. W. Bussmann, G. G. Gilbreath, J. Solio et al., "Plant use of the Maasai of Sekenani valley, Maasai Mara, Kenya," Journal of Ethnobiology and Ethnomedicine, vol. 2, no. 1, 2006.

[79] VOA Learninig English, Kenyan Team Aims to Stop Deadly Snake Bites, VOA Learninig English, Washington, DC, USA, 2019, https://learningenglish.voanews.com/a/kenyan-teamaim-to-stop-deadly-snake-bites/5147228.html.

[80] Access Campaign, Working with the Community to Tackle Snakebite: Baringo County, Kenya, Access Campaign, Geneva, Switzerland, 2019, https://msfaccess.org/working-communitytackle-snakebite-baringo-county-kenya.

[81] K. Ndambu, "Snake bite menace threatening lives in Kitui county,” 2016, https://reject.awcfs.org/article/snake-bitemenace-threatening-lives-in-kitui-county/. 